\title{
Evidence for a differential expression of the Fc\&RI $\gamma$ chain in dendritic cells of atopic and nonatopic donors
}

\author{
Natalija Novak, ${ }^{1}$ Carmen Tepel, ${ }^{2}$ Susanne Koch, ${ }^{1}$ Klaudia Brix, ${ }^{2}$ Thomas Bieber, ${ }^{1}$ \\ and Stefan $\mathrm{Kraft}^{1,3}$ \\ ${ }^{1}$ Department of Dermatology, and \\ ${ }^{2}$ Institute of Cell Biology and Bonner Forum Biomedizin, Friedrich-Wilhelms University, Bonn, Germany \\ ${ }^{3}$ Department of Pathology, Beth Israel Deaconess Medical Center, and Harvard Medical School, Boston, Massachusetts, USA
}

\begin{abstract}
While mast cells and basophils constitutively express the high-affinity IgE receptor (FcERI), it is absent or weakly expressed on APCs from normal donors. FcERI is strongly upregulated on APCs from atopic donors and involved in the pathophysiology of atopic diseases. Despite its clinical relevance, data about FcERI regulation on APCs are scarce. We show that in all donors intracellular $\alpha$ chain of the Fc\&RI (Fc\&RI $\alpha$ ) accumulates during DC differentiation from monocytes. However, expression of $\gamma$ chains of the Fc\&RI (FcERI $\gamma$ ), mandatory for surface expression, is downregulated. It is low or negative in DCs from normal donors lacking surface Fc\&RI (Fc\&RI ${ }^{\text {neg }}$ DCs). In contrast, DCs from atopics express surface FceRI (Fc\&RIpos DCs) and show significant FceRI $\gamma$ expression, which

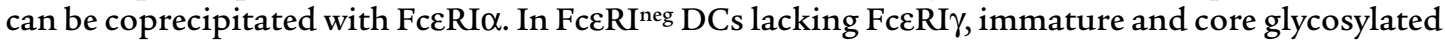

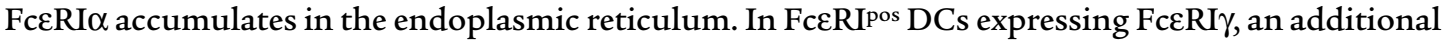
mature form of FceRI $\alpha$ exhibiting complex glycosylation colocalizes with FceRI $\gamma$ in the Golgi compartment. IgE binding sustains surface-expressed FcERI on DCs from atopic donors dependent on baseline protein synthesis and transport and enhances their IgE-dependent APC function. We propose that enhanced FcERI on DCs from atopic donors is driven by enhanced expression of otherwise limiting amounts of FceRI $\gamma$ and is preserved by increased IgE levels.
\end{abstract}

J. Clin. Invest. 111:1047-1056 (2003). doi:10.1172/JCI200315932.

\section{Introduction}

Ligation of the high-affinity IgE receptor (FcERI) on effector cells of anaphylaxis such as mast cells and basophils induces cell activation and immediate release of allergic mediators. FceRI on these cells shows a tetrameric structure of a heavily glycosylated $\alpha$ chain of the FceRI (FcERI $\alpha$ ), two $\gamma$ chains (FcERI $\gamma$ ) containing phosphoacceptors for signaling proteins, and a $\beta$ chain (FcERI $\beta$ ), which enhances FceRI surface expression and signaling (1). In addition, a trimeric form of FceRI lacking FcERI $\beta$ is found on human dedicated APCs such as DCs, including epidermal Langerhans' cells (LCs),

Received for publication May 14, 2002, and accepted in revised form December 17, 2002.

Address correspondence to: Thomas Bieber, Department of Dermatology, Friedrich-Wilhelms University, Sigmund-Freud Strasse 25, 53105 Bonn, Germany. Phone: 49-228-287-4388; Fax: 49-228-287-4881; E-mail: Thomas.Bieber@ukb.uni-bonn.de. Conflict of interest: The authors have declared that no conflict of interest exists.

Nonstandard abbreviations used: high-affinity IgE receptor (FcERI); $\alpha$ chain of the FcERI (FcERI $\alpha$ ); $\gamma$ chains of the FcERI (FcERI $\gamma) ; \beta$ chain of the FceRI (FcERI $\beta$ ); Langerhans' cell (LC); inflammatory dendritic epidermal cell (IDEC); atopic dermatitis $(\mathrm{AD})$; phycoerythrin (PE); protein disulfide isomerase (PDI); peroxidase (POD); monocyte-derived dendritic cell (MoDC); endoglycosidase $\mathrm{H}$ (Endo $\mathrm{H}$ ); anti-4-hydroxy-3-iodo-5nitrophenyl-acetyl (NIP); NIP-haptenized tetanus toxoid (NIP-TT); relative stimulation index (rSI); negligible FceRI surface expression on DC (FcERI $\left.{ }^{\text {neg }} D C\right)$; significant FcERI surface expression on DC (FcERIpos DC); brefeldin A (BFA);

cycloheximide (CHX); chimeric IgE (cIgE). blood DCs, and monocytes (2-7). APCs bearing trimeric FceRI can efficiently present IgE-bound antigens to $T$ cells in an IgE-mediated delayed-type hypersensitivity reaction $(6,8,9)$, putatively playing an important role in the pathophysiology of atopic diseases $(10,11)$.

The mechanisms regulating FceRI expression on APCs are of particular interest because, in contrast to constitutive expression on effector cells of anaphylaxis, FcERI surface expression is associated with the atopic status of the donors. Healthy donors often show low or no surface FceRI on APCs, depending on the cell type, whereas atopic donors display high levels $(5,7,12,13)$. Only FceRI expressed in significant amounts, i.e., on APCs of atopic donors, may mediate sufficient signaling and effector functions (11). A role of FcERI in atopic diseases can be undermined by in vivo observations, such as the emergence of inflammatory dendritic epidermal cells (IDECs), which are present in inflammatory skin, and in atopic dermatitis (AD) show very high FcERI levels (14). The mechanisms guiding such in vivo phenomena are unknown. Studies about basic mechanisms of FcERI regulation have been done using in vitro reconstitution systems and effector cells of anaphylaxis. In rodents a tetrameric structure of FceRI is obligatory, whereas FceRI expressed in humans requires a minimal trimeric structure without $\operatorname{Fc\varepsilon RI} \beta(15,16)$. FceRI $\gamma$ is mandatory for in vitro $\alpha \gamma_{2}$ and $\alpha \beta \gamma_{2}$ receptor surface expression $(16,17)$. Regarding FcERI assembly and maturation (18-21), folding and core glycosylation of immature FceRI $\alpha$ in the ER are followed by trimming 
of terminal glucose residues. The export of immature FceRI $\alpha$ from the ER to the Golgi compartment is controlled by correct trimming and association with the FceRI $\gamma$ chains. Then terminal glycosylation with complex sugars follows, and mature FcERI is transported to the cell surface. FceRI $\beta$ enhances this process, leading to increased surface expression of FcERI.

In APCs, IgE and IL-4 can enhance FceRI expression on monocytes and THP- 1 cells $(7,13,22)$. Human LCs are immature DCs forming sentinels of the immune system in the skin and express an intracellular FcERI $\alpha$ pool irrespective of the atopic status. Increased FceRI surface levels are associated with upregulation of FceRI $\gamma(23)$. However, detailed analyses of FceRI subunit regulation in LCs are limited because of insufficient availability. In addition, LCs show spontaneous differentiation into mature DCs, which is accompanied by the irreversible loss of FceRI $\alpha$ expression. To study FcERI regulation on DCs in detail, alternative systems have become available. DCs can be generated from peripheral monocytes with GM-CSF and IL-4 (24), and the differentiation stages can be controlled more easily. Using this system, we analyzed trimeric FceRI subunit regulation, localization, and its biochemical status in DCs with regard to the atopic status of donors.

\section{Methods}

Reagents. Phycoerythrin-labeled (PE-labeled) T6/RD1 $\mathrm{mAb}$ (Beckman Coulter GmbH, Krefeld, Germany) recognizes CD1a. The mAb's 22E7 (a kind gift from J. Kochan, Hoffman-La Roche Diagnostics, Nutley, New Jersey, USA) and 3G6 (Upstate Biotechnology Inc., Lake Placid, New York, USA) detect FceRI $\alpha(25,26)$. RAB1 is a kind gift from T. Bjerke (Institute of Anatomy, University of Aarhus, Aarhus, Denmark) and is a polyclonal rabbit $\mathrm{Ab}$ against human FceRI $\alpha$. Polyclonal rabbit antiserum against FcERI $\gamma$ was from Upstate Biotechnology Inc. and mAb 4D8 was kindly provided by J. Kochan (see above). Rabbit polyclonal Ab's for organelle labeling were directed against protein disulfide isomerase (PDI) in the ER (StressGen Biotechnologies Corp., Victoria, British Columbia, Canada) and giantin in the Golgi compartment (a kind gift of Y. Misumi and Y. Ikehara, Fukuoka University, Fukuoka, Japan). The mAb against FcyRIII/CD16 (3G8) was from Jackson ImmunoResearch Laboratories Inc. (West Grove, Pennsylvania, USA). The mAb against Fc $\gamma R$ II/CD32 (IV.3) was from Medarex (Lebanon, New Hampshire, USA), and the mAb against Fc $\gamma R \mathrm{RI} / \mathrm{CD} 64$ (mAb 10.1) was purchased from PharMingen (San Diego, California, USA). Human myeloma IgE was obtained from Calbiochem-Novabiochem $\mathrm{GmbH}$ (Bad Soden, Germany). FITC-, Cy2-, and Cy3-labeled F(ab')2 fragments of goat anti-mouse $\mathrm{Fc} \mathrm{Ab}$ as well as $\mathrm{Cy} 2$ - and $\mathrm{Cy} 3$-labeled goat anti-rabbit $\mathrm{Ab}$ were purchased from Jackson ImmunoResearch Laboratories Inc. Alexa Fluor 488-nm goat anti-mouse $\mathrm{F}\left(\mathrm{ab}^{\prime}\right) 2$ fragments were from Molecular Probes Inc. (Eugene, Oregon, USA). PE-labeled anti-CD14 Ab was from Becton Dickinson
Immunocytometry Systems (San Jose, California, USA). Peroxidase-conjugated (POD-conjugated) goat anti-mouse Ig Ab was obtained from Bio-Rad Laboratories Inc. (Richmond, California, USA). POD-conjugated goat anti-rabbit Ig Ab, poly-L-lysine, digitonin, and saponin were from Sigma-Aldrich (St. Louis, Missouri, USA).

Monocyte isolation and generation of monocyte-derived dendritic cells. Atopic donors were showing a clinical history of atopic dermatitis, and/or allergic asthma, and/or allergic rhinoconjunctivitis, and elevated serum $\operatorname{IgE}(>100 \mathrm{kU} / \mathrm{l})$ and were not subject to therapy. Nonatopic donors exhibited none of these parameters. They were selected in accordance with the local ethics committee and gave written informed consent. Monocytes were isolated from peripheral blood with a modified density-gradient protocol using Nycoprep (Nycomed, Oslo, Norway). Briefly, red blood cells were separated from plasma by sedimentation from EDTA blood with one-tenth (wt/vol) $6 \%$ dextran 500 in $0.9 \%$ $\mathrm{NaCl}$. Plasma was layered over Nycoprep and centrifuged for $20 \mathrm{~min}$ at $600 \mathrm{~g}$. After separation, the interphase and upper part of the Nycoprep were collected and washed four times with $0.9 \% \mathrm{NaCl}$ plus $0.13 \%$ EDTA plus 1\% BSA. Then, CD14 expression was assessed, and isolated monocytes were cultured for up to 8 days with $500 \mathrm{U} / \mathrm{ml}$ GM-CSF (Genzyme Pharmaceuticals, Cambridge, Massachusetts, USA) and $500 \mathrm{U} / \mathrm{ml} \mathrm{IL-4}$ (Life Technologies GmbH, Eggenstein, Germany) to yield immature monocyte-derived dendritic cells (MoDCs). For analysis of effects on FcERI regulation, myeloma IgE was initially added at $1 \mu \mathrm{g} / \mathrm{ml}$ at day 0 and $0.5 \mu \mathrm{g} / \mathrm{ml}$ at days 2 and 4 . To assess the mechanism of FceRI upregulation, IgE was added at $1 \mu \mathrm{g} / \mathrm{ml}$ at day $4 \pm$ cycloheximide (SigmaAldrich) or \pm brefeldin A (GolgiPlug; PharMingen), both at $1 \mu \mathrm{g} / \mathrm{ml}$. These inhibitors did not affect cell viability determined by 7 -aminoactinomycin-D and apoptosis staining. Stimulation of immature MoDCs with TNF- $\alpha$ (100 U/ml) (Genzyme Pharmaceuticals) was performed for 2 days to achieve final maturation. Contamination of monocyte and DC preparations with mast cells or basophils was excluded by staining with anti-CD117 (Becton Dickinson Immunocytometry Systems) and anti-CD203c (Immunotech, Marseille, France) $\mathrm{mAb}$.

Flow-cytometric analysis. Double-staining experiments with saponin or digitonin for the detection of surface or intracellular FcERI chains were performed as described $(3,14,27)$. Saponin permeabilization was used for detection of intracellular FceRI $\alpha$, whereas digitonin was used for detection of FcERI $\gamma$ expression as reported (23). Cells were acquired using a FACSCalibur flow cytometer (Becton Dickinson Immunocytometry Systems). For quantitative evaluation, the CD1 $a^{\text {pos }}$ or CD14pos population was gated manually, and the percentage of FceRI $\alpha$ - or FcERI $\gamma$-positive was determined using CellQuest software (Becton Dickinson Immunocytometry Systems). 
Confocal laser scan microscopy. For staining of FceRI chains and organelle labeling, $3 \times 10^{5}$ cells were washed with PBS and adhered to coverslips coated with poly-Llysine solution. Cells were incubated in PBS plus $0.2 \%$ BSA, fixed with PBS plus 8\% paraformaldehyde, then incubated with PBS plus $0.1 \mathrm{M}$ glycine, separated by washes with PBS. Permeabilization was performed for 30 min with saponin buffer (PBS plus $0.5 \%$ BSA plus $0.1 \%$ saponin), followed by blocking with $0.5 \mathrm{mg} / \mathrm{ml}$ human IgG Fc for $30 \mathrm{~min}$. Incubation with primary $\mathrm{Ab}$ was performed overnight at $4^{\circ} \mathrm{C}$. After four washes with saponin buffer, the coverslips were incubated with FITC-, Cy2-, or Cy3-labeled secondary Ab for $60 \mathrm{~min}$ at room temperature. Then, four washes were performed again. Additional blocking and staining steps as described above were performed with another set of non-crossreactive primary and secondary Ab's to achieve labeling of a second epitope. After staining, the samples were washed with saponin buffer and then PBS. Finally, the coverslips were sealed and analyzed on a Zeiss LSM510 microscope (Carl Zeiss Jena GmbH, Jena, Germany) using Zeiss LSM 510 Image Browser/Examiner software.

Immunoprecipitation of FcERI $\alpha$, endoglycosidase $H$ treatment, and Western blotting analysis. For immunoprecipitation of FceRI $\alpha$, cells were lysed in $100 \mathrm{mM}$ boric acid with $80 \mathrm{mM} \mathrm{NaCl}, 0.5 \%$ Triton X-100 (1\% digitonin for coimmunoprecipitation of FcERI $\gamma$, and protease inhibitors. After preclearing with protein $\mathrm{G}$ agarose (Santa Cruz Biotechnology Inc., Santa Cruz, California, USA), anti-FceRI $\alpha$ mAb 3 G6 was added for overnight incubation. Then, protein $\mathrm{G}$ agarose was added for $2 \mathrm{~h}$. After three washing steps, proteins were eluted with $2 \mathrm{x}$ Laemmli buffer. Treatment of FcERI $\alpha$ with endoglycosidase $\mathrm{H}$ (Endo H) (New England Biolabs Inc., Beverly, Massachusetts, USA) was done according to the manufacturer's instructions.

Immunoprecipitates or cell lysates were subject to $10 \%$ or $18 \%$ SDS-PAGE and blotted to nitrocellulose membranes. After blocking, proteins were identified using the Ab RAB1 for FceRI $\alpha$ and 4D8 for FceRI $\gamma$ (both 1:1,000) or appropriate controls. The bands were visualized with $\mathrm{POD}$-conjugated $\mathrm{Ab}$ followed by the ECL system (Amersham Pharmacia Biotech, Piscataway, New Jersey, USA).

Amplification of $m R N A$ and analysis of FcERI transcripts. MoDCs at day 4 of culture were further incubated with or without the addition of $1 \mu \mathrm{g} / \mathrm{ml}$ human myeloma IgE. After 24 and $48 \mathrm{~h}$, total RNA was extracted from highly purified MoDCs using Trizol (Life Technologies $\mathrm{GmbH}$ ) following the manufacturer's instructions. RT reactions were performed using $1 \mu \mathrm{g}$ of RNA. Denaturation at $94^{\circ} \mathrm{C}$ for $40 \mathrm{~s}$ was followed by primer annealing at $55^{\circ} \mathrm{C}$ for $30 \mathrm{~s}$ and extension at $72^{\circ} \mathrm{C}$ for $30 \mathrm{~s}$. A final extension phase of $5 \mathrm{~min}$ was added. Specific primer sequences for each gene were as follows: human $\beta$-actin, sense, $5^{\prime}$-GAG CGG GAA ATC GTG CGT GAC ATT$3^{\prime}$; antisense, $5^{\prime}$-GAT GGA GTT GAA GGT AGT TTC GTG$3^{\prime}$, yielding a 240-bp fragment; human FceRI $\alpha$, sense,
5'-CTG TTC TTC GCT CCA GAT GGC GT-3'; antisense, 5'TAC AGT AAT GTT GAG GGG CTC AG-3' (536-bp fragment), and human FceRI $\gamma$, sense, $5^{\prime}$-CCA GCA GTG GTC TTG CTC TTA C- $3^{\prime}$ and antisense, $5^{\prime}$-GCA TGC AGG CAT ATG TGA TGC C-3'(338-bp fragment). Amplification was performed on a Perkin-Elmer Gene Amp PCR System 9600 thermocycler (Applied Biosystems GmbH, Weiterstadt, Germany). The PCR cycle numbers for the amplification of the respective cDNAs were 25 for $\beta$-actin and 30 for FceRI $\alpha$ and FceRI $\gamma$. Specific PCR fragments were separated on a $1 \%$ agarose gel and visualized using ethidium bromide staining. The PCR products were evaluated semiquantitatively by comparing the ratio of the specific products versus the $\beta$-actin band by digital image analysis using the WinCam system (Cybertech, Berlin, Germany).

FcERI-mediated antigen uptake and T-cell proliferation assays. For $\mathrm{T}$ cell proliferation assays of FcERI-mediated antigen presentation to autologous T cells, MoDCs were generated from the same donors and assayed under identical conditions. Proliferation assays were performed in a total volume of $200 \mu \mathrm{l}$ in 96-well round-bottom plastic culture plates using autologous $T$ cells. T cells were isolated from PBMCs using a nylon-wool column (>85\% purity was assessed by anti-CD3 staining).

MoDCs from atopic and nonatopic donors (three each) were cultured as described above $\pm 1 \mu \mathrm{g} / \mathrm{ml}$ chimeric human anti-4-hydroxy-3-iodo-5-nitrophenyl-acetyl (NIP) IgE (cIgE) (JW8/1; Serotec, Oxford, United Kingdom) until day 6 of culture. On day 6, FceRI expression was quantified using flowcytometric staining. MoDCs were washed three times and incubated with $1 \mu \mathrm{g} / \mathrm{ml} \mathrm{cIgE}$ for $1 \mathrm{~h}$. After washing, the cells were loaded with NIP-haptenized tetanus toxoid (NIP-TT) (28). As a control, MoDCs were loaded with cIgE, or NIP-TT alone, or left unloaded. Then MoDCs were irradiated ( $3 \mathrm{~Gy})$ and seeded with autologous T cells at $2 \times 10^{4}(1: 10$ or $1: 100 \mathrm{MoDC} / \mathrm{T}$ cells) cells/well in 96 -well culture plates at $37^{\circ} \mathrm{C}$ for $96 \mathrm{~h}$. Each condition was done in triplicate. Twenty microliters of ${ }^{3} \mathrm{H}$-thymidin (Amersham Pharmacia Biotech) was added to each well and incubated for another $16 \mathrm{~h}$. Culture plates were harvested, and the incorporated radioactivity was measured in a liquid scintillation counter. Relative stimulation indices (rSI's) were calculated as follows: $r S I=(\mathrm{cpm}(\mathrm{SMLR})-$ cpm ( $\mathrm{T}$ cell)/cpm ( $\mathrm{T}$ cell).

Statistical analysis. For statistical evaluation, Wilcoxon or Mann-Whitney $U$ tests were performed with SPSS 10.0 for Windows. Results are given in mean percentage of positive cells \pm SEM. A $P$ value less than 0.05 was considered to be significant.

\section{Results}

Differentiation of monocytes toward DCs results in intracellular accumulation of FcERI $\alpha$ and downregulation of FcERI $\gamma$. FcERI surface expression on monocytes is upregulated in atopic donors $(5,13)$, although in another study no direct correlation to the serum IgE level was found (29). 

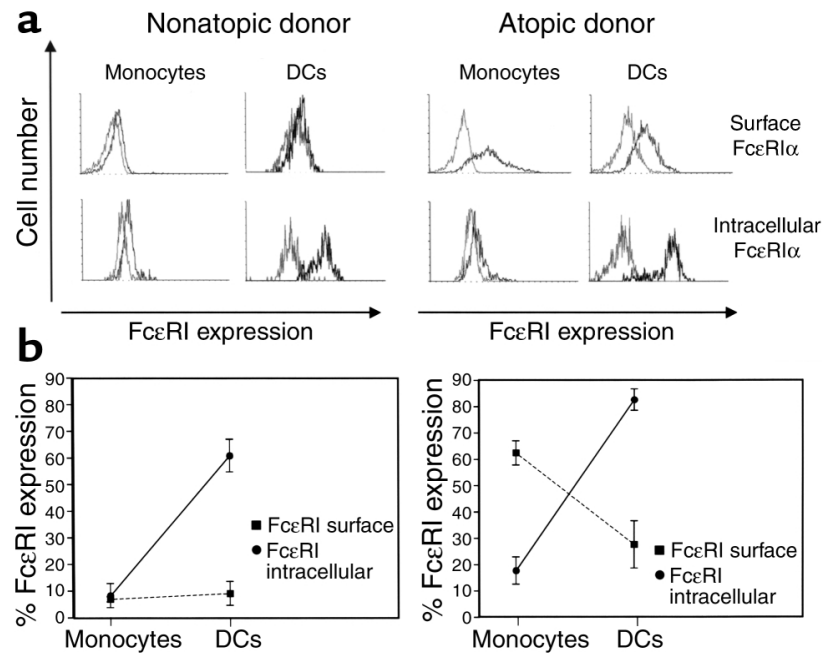

Figure 1

FcERI surface and intracellular expression in monocytes and DCs from nonatopic and atopic donors. (a) For surface staining, cells were subject to double immunolabeling using anti-FcERI $\alpha$ mAb 22E7, anti-CD14 or anti-CD1 a mAb, and 7-aminoactinomycin-D for dead cell discrimination. For intracellular staining, fixation with $4 \%$ formaldehyde and permeabilization with $0.5 \%$ saponin was done before staining. Acquisition was performed on a FACSCalibur flow cytometer. Shown are histograms from CD14pos or CD1 apos cells (day 8), which represent typical data for at least ten experiments for each donor group. (b) Data were obtained as described for (a). Shown are at least three experiments for each parameter (mean of percentage of positive cells \pm SEM).

In our previous work on FcERI in epidermal LCs, the paradigmatic immature DCs, high FceRI $\alpha$ levels were observed intracellularly, irrespective of FcERI surface expression, which depends on the atopic status of the donors $(14,23)$. To analyze the expression of FceRI $\alpha$ during differentiation of monocytes toward DCs, we performed a detailed analysis of surface and intracellular expression of FcERI $\alpha$ with regard to the atopic status of donors. Figure 1a shows typical data from donors representative for ten experiments for each group. Whereas normal donors showed negligible FcERI surface expression on monocytes and DCs (FceRIneg DC) at day 8, monocytes and DCs from atopic donors showed significant FceRI surface expression (FcERIpos DC). Interestingly, monocytes from both groups showed very low intracellular expression of FcERI $\alpha$, whereas DCs generated from these cells consistently showed high levels of intracellular FceRI $\alpha$ both in DCs from atopics and nonatopics (Figure 1b). To compare expression of FceRI $\alpha$ and FcERI $\gamma$ subunits during differentiation, we performed immunoblot analyses with FceRIpos monocytes and MoDCs from atopic donors. Again, we found a strong upregulation of FcERI $\alpha$ represented by two bands at 50-60 and 60-70 $\mathrm{kDa}$ in MoDCs compared with monocytes (Figure 2a). In contrast, FcERI $\gamma$ was found to be strongly expressed in monocytes, whereas in MoDCs only low amounts were detected (Figure $2 \mathrm{~b}$ ). Since Fc $\gamma \mathrm{RI} / \mathrm{CD} 64$ and $\mathrm{Fc} \gamma \mathrm{RIII} / \mathrm{CD} 16$ can share $\gamma$ chains with
FceRI $\alpha(30,31)$, we monitored their expression during differentiation. Figure $2 \mathrm{c}$ shows a rapid downregulation of IgG receptors, i.e., Fc $\gamma R \mathrm{RI} C \mathrm{CD} 64$, Fc $\gamma \mathrm{RII} / \mathrm{CD} 32$, and FcyRIII/CD16, during differentiation into DCs. Since

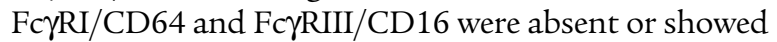
negligible levels of surface expression in DCs at day 8, an association of FceRI $\gamma$ with these structures is unlikely. In LCs we observed a rapid downregulation of FcERI after spontaneous in vitro differentiation (23). Similarly, Figure $2 \mathrm{~d}$ shows that maturation of immature MoDCs into $\mathrm{CD}^{+} 3^{+} \mathrm{DCs}$ for 2 more days of culture with TNF- $\alpha$ significantly downregulates FceRI expression on DCs from both atopic and nonatopic individuals $(n=6 ; P<0.05)$.

Immature FcERI $\alpha$ represent the majority of preformed intracellular FcERI $\alpha$ found in MoDCs, but FcERIpos DCs from atopics also exhibit mature FcERI $\alpha$. In models using transfected cells, it has been shown that export of FcERI $\alpha$ from the ER is dependent upon association with FceRI $\gamma$ and a glycosylation-dependent quality control mechanism (18-21). To assess (a) the maturity state of FceRI $\alpha$ accumulated in DCs and to investigate (b) whether the different FceRI surface levels observed between FceRIpos DCs from atopics and FcER Ineg DCs from nonatopics may be associated with different maturity states, we precipitated FcERI $\alpha$ from DCs. FcERI $\alpha$ was then treated with Endo H, which deglycosylates immature ER glycoproteins but not mature glycoproteins having undergone complex glycosylation in

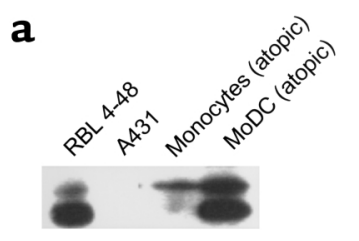

FceRl $\alpha$

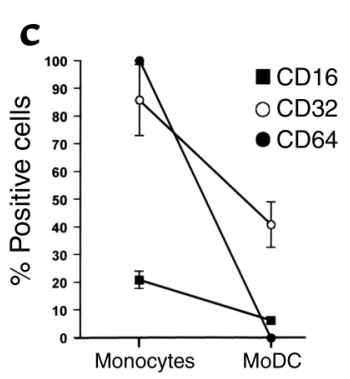

b
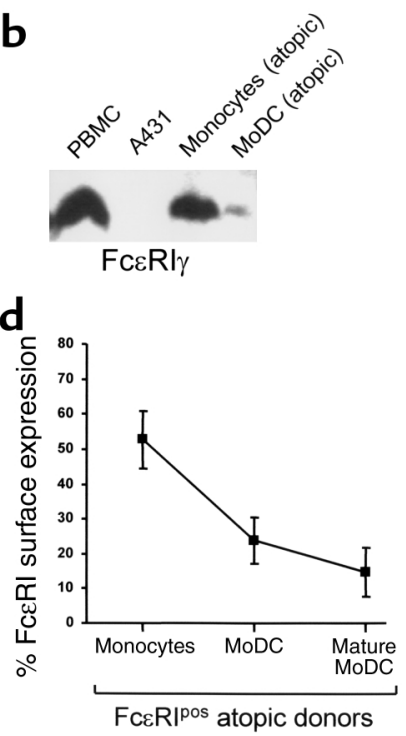

Figure 2

DCs generated from monocytes accumulate Fc\&RI $\alpha$, whereas Fc\&RI $\gamma$ and Fc $\gamma$ receptors are downregulated during differentiation. (a and b) Lysates from monocytes or MoDCs (> $90 \%$ purity), as well as RBL 4-48 cells stably expressing human FcERI $\alpha$, A431 epithelial cells, and PBMCs used as controls, were fractionated on SDS-PAGE and immunoblotted with $A b$ for $F_{C \varepsilon R I} \alpha$ or FcERI $\gamma$. (c) Expression of the Fc $\gamma$ receptors CD16, CD32, and CD64 was determined by flow cytometry as described for a. (d) Mature DCs were generated by addition of TNF- $\alpha$ to MoDC cultures. Flow cytometric analysis of FcERI expression of six donors was done as described for Figure 1a. 


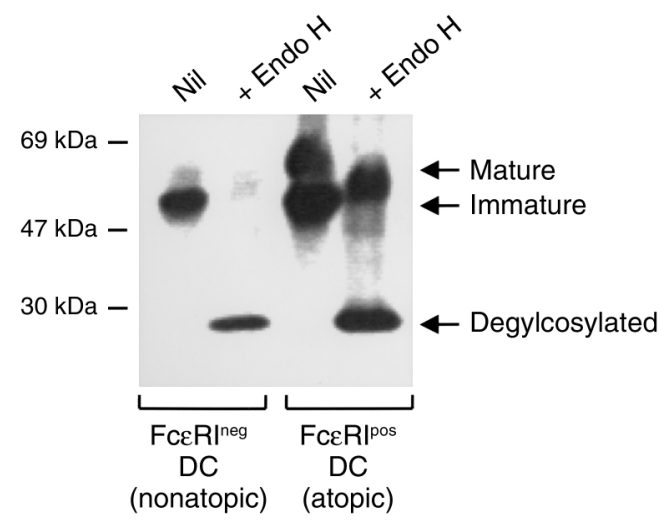

Figure 3

Immature FceRI $\alpha$ is found both in FceRIpos from atopics and FcERIneg DCs from nonatopics, whereas mature FcERI $\alpha$ is found only in FceRIpos DCs. Lysates from FcERI neg and FceRIpos DCs were subject to immunoprecipitation using $3 G 6$ anti-FceRI $\alpha$ Ab. Precipitated FcERI $\alpha$ was treated with Endo $H$, fractionated by SDSPAGE, and then immunoblotted using RAB1 anti-FcERI $\alpha$ Ab to detect immature (Endo $\mathrm{H}$-sensitive) or mature (Endo $\mathrm{H}$-resistant) forms. Nil, without Endo $\mathrm{H}$ treatment.

the Golgi compartment $(18,19)$. As shown in Figure 3, a major proportion of the FcERI $\alpha$ protein precipitated both from FceRIpos and FceRI ${ }^{\text {neg }}$ DCs consists of a glycoprotein of $50-60 \mathrm{kDa}$, which is sensitive to Endo $\mathrm{H}$ treatment, yielding a $25-30 \mathrm{kDa}$ core protein band. Thus, this 50-60 kDa protein may represent ER-resident immature FcERI $\alpha$. In addition, FcERIpos DCs from atopics exhibited a band at $60-70 \mathrm{kDa}$ resistant to Endo $\mathrm{H}$, presumably representing a mature form from the Golgi compartment or the cell surface.

The subcellular localization of FcERI subunits in FcERI $I^{\text {pos }}$ and FcER ${ }^{\text {neg }} D C$ s show a different distribution. The biochemical analyses shown above suggest that most of FceRI $\alpha$ accumulated during DC differentiation is ER localized. In addition, mature FcERI $\alpha$ detected in lysates from FceRIpos DCs should also be detectable in the Golgi compartment. To further confirm these observations, the distribution of the FceRI subunits was analyzed by confocal laser scan microscopy (see Figure 4). CD14 or CD1a positivity of FceRI-labeled cells was confirmed using double immunolabeling (data not shown). In contrast to normal donors, freshly isolated monocytes from atopic donors exhibited membrane-localized FceRI $\alpha$ colocalizing with FceRI $\gamma$ subunits. Some few, FceRI $\gamma$-positive but FceRI $\alpha$-negative, monocytes were also present in these preparations. After differentiation toward DCs, a strong

\section{Figure 4}

Monocytes, FcERIpos, and FcERI neg DCs show a different localization of FcERI subunits. Cells were adhered to coverslips, fixed, and permeabilized using $0.1 \%$ saponin. After blocking using human IgG Fc, sequential indirect immunolabeling with $A b$ against $F c \varepsilon R I$ subunits and organelle markers was performed. After mounting, the samples were analyzed by confocal laser scanning microscopy. intracellular FceRI $\alpha$ expression was observed, while FcERI surface expression was weaker under these experimental conditions, presumably due to its downregulation and to changes in the plasma membrane architecture. In nonpermeabilized cells, however, it could be detected better (data not shown). While the majority of FcER ${ }^{\text {neg }}$ DCs from nonatopics showed a strong intracellular expression of FceRI $\alpha$ localized in the ER (colocalized with anti-PDI), they lacked FcERI $\gamma$ expression or showed a discrete staining pattern. In contrast, FceRIpos DCs from atopics showed colocalization of FceRI $\alpha$ and FceRI $\gamma$ subunits together, mainly in the Golgi compartment (colocalized with antigiantin) in addition to the ER localization also observed in FceRI Ineg DCs. Taken together, these data confirm that DCs acquire an intracellular pool of FceRI $\alpha$ localized in the ER in FceR Ineg DCs. In FceRIpos DCs from atopics, which coexpress the $\gamma$ chain, it is allowed to reach the Golgi compartment and, subsequently, the cell surface.

FcERI $\gamma$ controls the surface expression of FcERI $\alpha$ in DCs. In in vitro reconstitution models and in mast cells, surface expression of FcERI $\alpha$ is critically dependent on FcERI $\gamma$ expression $(16,17,32)$. We reported a correlation between FceRI $\alpha$ surface levels and FceRI $\gamma$ expression at mRNA and protein levels in human LCs (23). Since our data show abundant FceRI $\alpha$ in MoDCs with no or little regard to the atopic status of donors, differential FcERI $\gamma$ expression in DCs from normal and atopic individuals could explain the dichotomy observed in FceRI surface expression. We therefore analyzed both FceRI

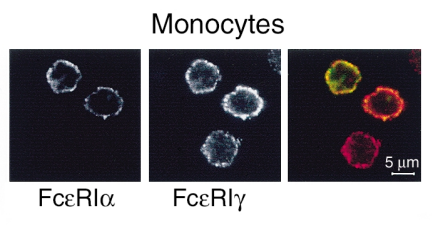

FceRI pos atopic MoDC

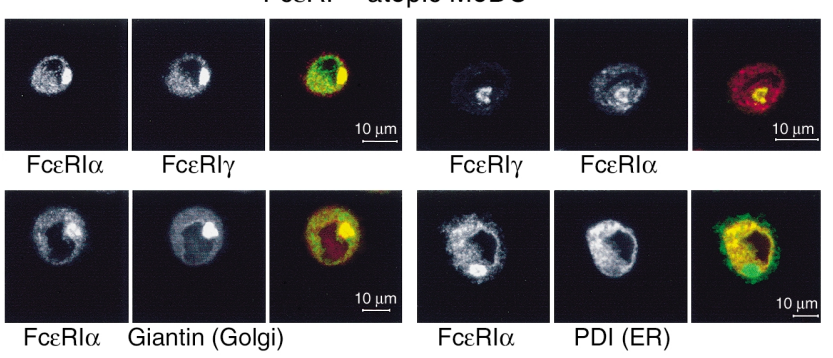

FceRI $\left.\right|^{\text {neg }}$ nonatopic MoDC

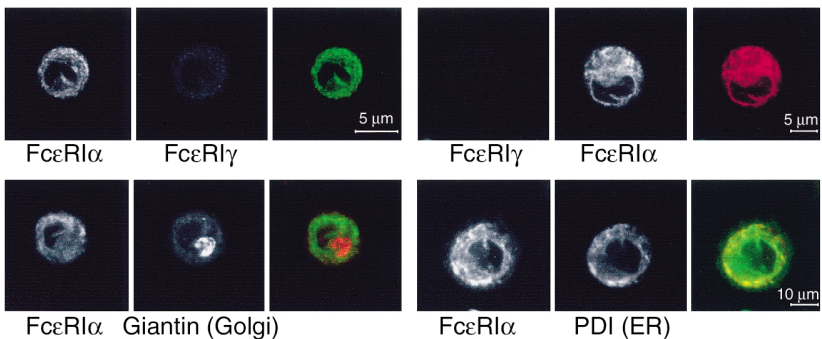



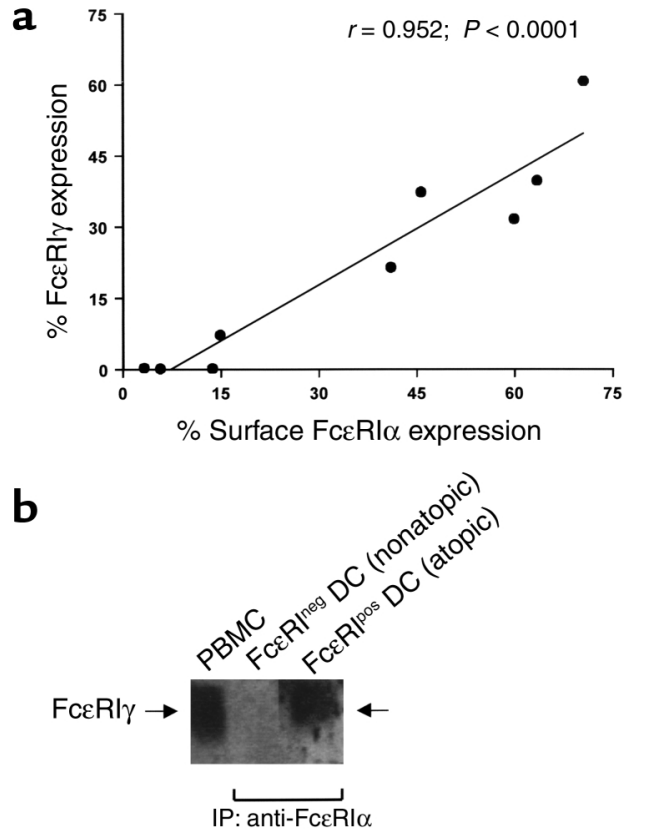

Figure 5

Significant FcERI $\gamma$ expression and association of FcERI $\alpha$ with FcERI $\gamma$ can be detected only in FcERIpos DCs from atopic donors. (a) FcERI $\gamma$ expression was determined by double immunolabeling of MoDCs using anti-FcERI $\gamma$ and anti-CD1a after a mild permeabilization with digitonin to preserve surface-expressed FcERI complexes. Determination of FcERI surface expression and flow-cytometric analysis was done as described for Figure 1. (b) FcERI ${ }^{\text {neg }}$ (4\% positive cells) and FcERIpos (86\% positive cells) DCs were subject to mild lysis with a buffer containing $1 \%$ digitonin followed by immunoprecipitation using $3 \mathrm{G} 6$ anti-FcERI $\alpha \mathrm{Ab}$ and SDS-PAGE. FcERI $\gamma$ coprecipitated with FcERI $\alpha$ was detected by immunoblotting using 4D8 Ab. PBMC lysates were used as positive controls.

surface expression and FceRI $\gamma$ protein levels in 6-dayold MoDCs from donors of atopic (FcERIpos DCs) and normal backgrounds (FcERI $\left.{ }^{\text {neg }} \mathrm{DCs}\right)(n=9)$. Figure 5a shows a highly significant correlation between the expression levels of these two structures $(r=0.952$; $P<0.0001)$. To investigate whether FceRI $\gamma$ is indeed associated in DCs positive for surface FceRI, we precipitated FceRI $\alpha$ from FceRI ${ }^{\text {neg }}$ and FceRIPos DCs under mild lysis conditions using $1 \%$ digitonin (19). Figure $5 \mathrm{~b}$ shows that FceRI $\gamma$ was coprecipitated with FceRI $\alpha$ in FceR ${ }^{p o s}$ DCs from atopics, but not in FceRI ${ }^{\text {neg }}$ DCs from nonatopics (despite strong intracellular FcERI $\alpha$ expression in both groups, data not shown). Thus, we conclude that remaining, moderate FcERI $\gamma$ expression in DCs from atopics - as opposed to low or absent FceRI $\gamma$ expression in DCs from nonatopics - is sufficient to keep significant FceRI surface levels on these cells.

An "atopic environment" provided by IgE sustains FceRI surface expression in DCs. While as yet unknown factors that induce $\gamma$-chain expression may provide DCs from atopics with higher baseline FceRI surface expression, the maximal levels, e.g., seen during active $\mathrm{AD}$, may be regulated by additional factors. In effector cells of anaphylaxis, IgE levels positively regulate FcERI surface expression (33-35), but it is unclear whether the ligand may influence the level of FceRI on DCs. We therefore tested the effect of human myeloma IgE on FceRI expression added every 2 days during DC differentiation. Preliminary experiments showed that an initial dose of $1 \mu \mathrm{g} / \mathrm{ml}$ of IgE was optimal and did not affect the phenotype and apoptosis rate. While addition of IgE failed to induce any FceRI surface expression at different time points on FcER Ineg DCs from nonatopic donors (data not shown), DCs from atopic individuals exhibited significantly higher FceRI levels with IgE than DCs generated under control conditions (Figure 6a). We performed a number of additional experiments to investigate the mechanism of IgE-mediated effect: to determine whether $\operatorname{IgE}$ induces the transcription of FcERI chains, we performed semiquantitative RT-PCR with DCs that were incubated with $1 \mu \mathrm{g} / \mathrm{ml} \operatorname{IgE}$ for up to $48 \mathrm{~h}$. The experiments showed no significant upregulation of either FcERI $\alpha$ or FcERI $\gamma$ transcripts after addition of $\operatorname{IgE}$ in five donors (Figure $6 \mathrm{~b}$ shows a representative PCR experiment from an atopic donor). Upregulation of surface FceRI by IgE on MoDCs from three atopic donors was confirmed by flow cytometry $(59.5 \% \pm 4.01 \%$ FceRI surface expression with IgE incubation and $14.9 \% \pm 8.7 \%$ FceRI surface expression without IgE incubation), whereas MoDCs from two nonatopic donors showed no upregulation.

In addition, we detected that MoDCs that were incubated with IgE until day 4 display enhanced FcERI $\gamma$ protein levels on day 6 of culture (Figure $6 c$ shows one representative experiment of three). To investigate the role of forward intracellular protein transport in the IgE-mediated effect on surface FcERI, IgE was added at day 4 with or without brefeldin A (BFA) and FceRI surface expression was analyzed every $24 \mathrm{~h}$. For those experiments, Fc\&RIpos DCs showing strong downregulation during DC differentiation were selected. As shown in Figure 6d, IgE addition at day 4 of culture restored FcERI levels almost completely to levels comparable to monocytes at the beginning of culture. BFA abolished this process as early as $24 \mathrm{~h}$ after its addition, demonstrating that both basal and IgE-mediated sustained FcERI surface expression are heavily dependent on forward protein transport. The protein synthesis inhibitor cycloheximide (CHX) also had a strong effect on basal and IgE-mediated sustained FceRI surface expression (Figure 6e). However, in the first $24 \mathrm{~h}, \operatorname{IgE}$ was able to counteract the CHX-mediated downregulation of surface FcERI to a limited extent. The differential effects of BFA and CHX in this early phase suggest that the IgE-mediated upregulation is initially dependent on forward transport (i.e., ER to Golgi compartment) of preformed and/or recycling FceRI. To differentiate between these two possibilities, we incubated MoDCs for $12 \mathrm{~h}$ both with CHX and BFA to inhibit both protein synthesis and forward transport and analyzed total FcERI $\alpha$ protein by immunoblot. If receptor recycling occurred to a major extent, we would expect total FcERI $\alpha$ protein not to change much; if forward 
transport and processing of intracellular FceRI $\alpha$ played a major role, we would expect total FceRI $\alpha$ to go down significantly. These experiments showed FceRI $\alpha$ protein was massively downregulated, no matter if $\operatorname{IgE}$ was added or not (data not shown). In parallel, the FceRI $\alpha$ surface expression of MoDCs incubated with CHX and BFA was downregulated within 3.5 hours of culture (data not shown). In addition, we excluded that this loss of surface FceRI $\alpha$ resulted from CHX/BFAinduced apoptosis and necrosis of the cells (data not shown). This argues against a major role of receptor recycling in these processes, although we cannot exclude the possibility that FceRI is internalized for recycling, but is degraded intracellularly. Taken together, IgE-mediated enhancement of FcERI surface expression on MoDCs seems to be an accumulation process. It is dependent on continuous basal protein synthesis as well as processing and transport of intracellular FcERI protein more likely using an intracellular FceRI pool than recycling FcERI protein.

IgE-mediated FcERI upregulation of DCs from atopic donors enhances their capacity to induce proliferation of autologous $T$ cells in IgE-dependent antigen-presentation assays. FcERImediated antigen uptake, processing, and presentation is believed to be a highly efficient mechanism and putatively plays an important role in the pathophysiology of atopic diseases $(10,11)$. We speculated that IgEinduced preservation of surface FceRI on DCs from atopics might enhance these IgE-mediated functions. To test this hypothesis, we generated MoDCs from either atopic or nonatopic donors that were incubated with and without $1 \mu \mathrm{g} / \mathrm{ml}$ NIP-specific chimeric IgE (cIgE) during differentiation. To measure IgE-dependent DC antigen-presenting function, these were freshly loaded with NIP-specific IgE and then cocultured with autologous $\mathrm{T}$ cells as well as NIP-coupled tetanus toxoid. $\mathrm{T}$ cell proliferation was assessed by ${ }^{3} \mathrm{H}$-thymidine incorporation after $96 \mathrm{~h}$. Figure 7 shows one representative experiment out of three for each donor group. When DCs from nonatopic donors were used, an IgE-induced enhancement of antigen-presenting capacity was hardly detectable, even with IgE preincubation (left panel). In contrast, DCs from atopics targeted by specific IgE and antigen were able to induce higher $\mathrm{T}$ cell proliferation (right panel). Stimulatory capacity was even stronger when DCs generated under the influence of $\operatorname{IgE}$ and thus expressing higher FceRI levels, were used. This demonstrates that IgE-mediated sustained surface FcERI expression can lead to biologically important changes in DC function.

\section{Discussion}

The differential FceRI surface expression on monocytes observed between healthy and atopic donors is in line with previous reports $(5,13)$, whereas, to our knowledge, no data are available for MoDCs. Another group found no correlation between surface FcERI and serum-IgE levels on monocytes (29). The donors analyzed in this study contained not only healthy donors and donors with atopic diseases, but also those with hypereosinophilic syndromes, hyper-IgE syndrome, helminth infestation, and IgE myeloma, which may

\section{Figure 6}

Addition of IgE leads to sustained FcERI surface expression in DCs from atopic donors in a BFAand $\mathrm{CHX}$-sensitive process without affecting de novo synthesis of FcERI $\alpha$ and FcERI $\gamma$ chains. (a) IgE was added from day 0 of DC culture (atopic donors) with GM-CSF and IL-4. Immunolabeling and flow-cytometric analysis of FcERI surface expression was performed as described for Figure 1. Percentage of positive cells shown under $\mathbf{a}$ are the result of six independent experiments. (b) MoDCs (day 4) were incubated for 24 and $48 \mathrm{~h}$ with or without the addition of $1 \mu \mathrm{g} / \mathrm{ml}$ human myeloma IgE. After RNA isolation from highly purified MoDCs and reverse transcription, FcERI $\alpha$ and FcERl $\gamma$ expression was analyzed by semiquantitative PCR using $\beta$-actin as a control. Shown is a representative experiment from an atopic donor of five total experiments. In parallel, FcERI $\gamma$ protein levels of one representative experiment of MoDC on day 6 of culture incubated with $(+\operatorname{IgE})$ and without $\lg E(-\lg E)$ until day 4 of culture are shown (c). (d and e) MoDCs were generated with GM-CSF and IL-4 until day 4 of culture. Then $\lg E, C H X$, and BFA (all $1 \mu \mathrm{g} / \mathrm{ml}$ ) were added as indicated. Flowcytometric analyses of FcERI expression were done on days indicated. Mean FcERI expression \pm SEM $(n=7)$ is shown as percentage of FcERI expression of monocytes at day 0 .
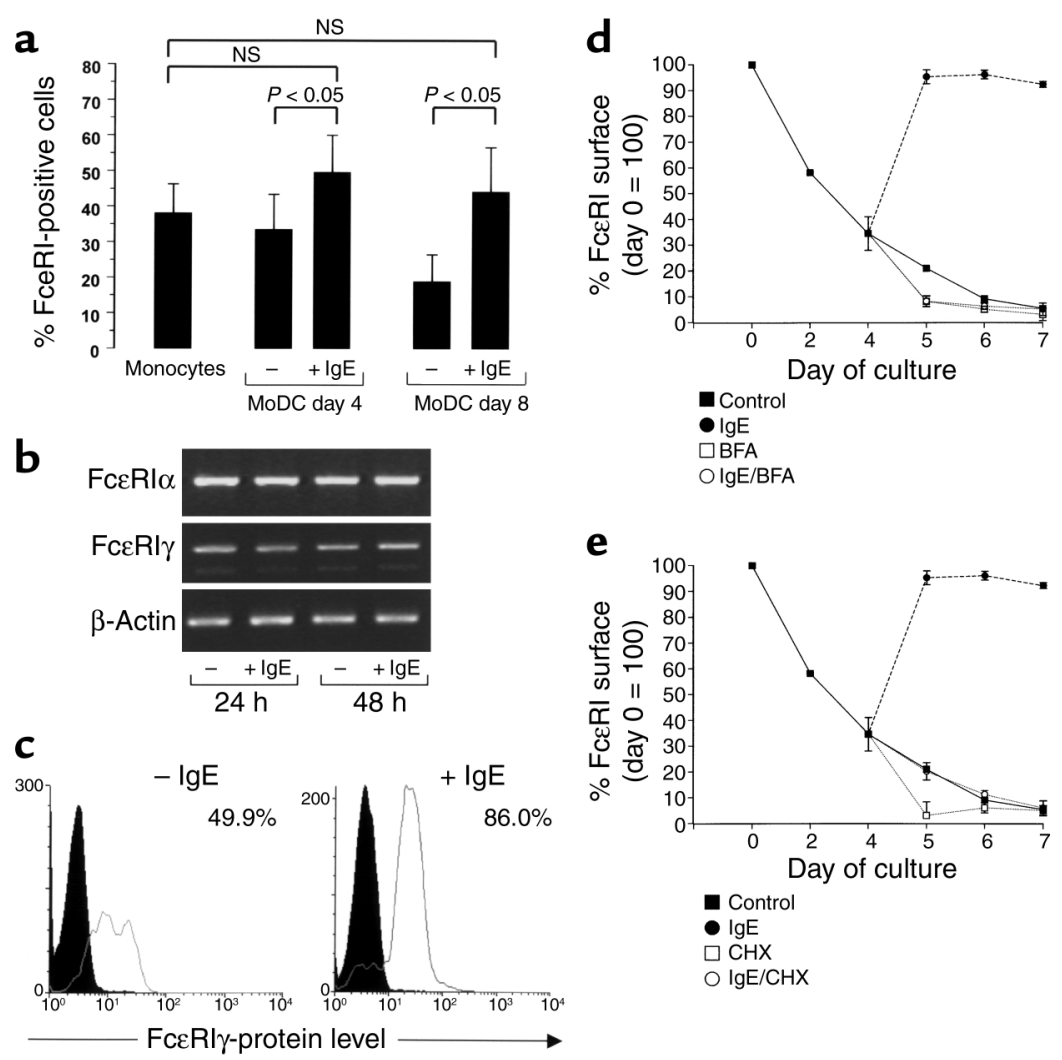

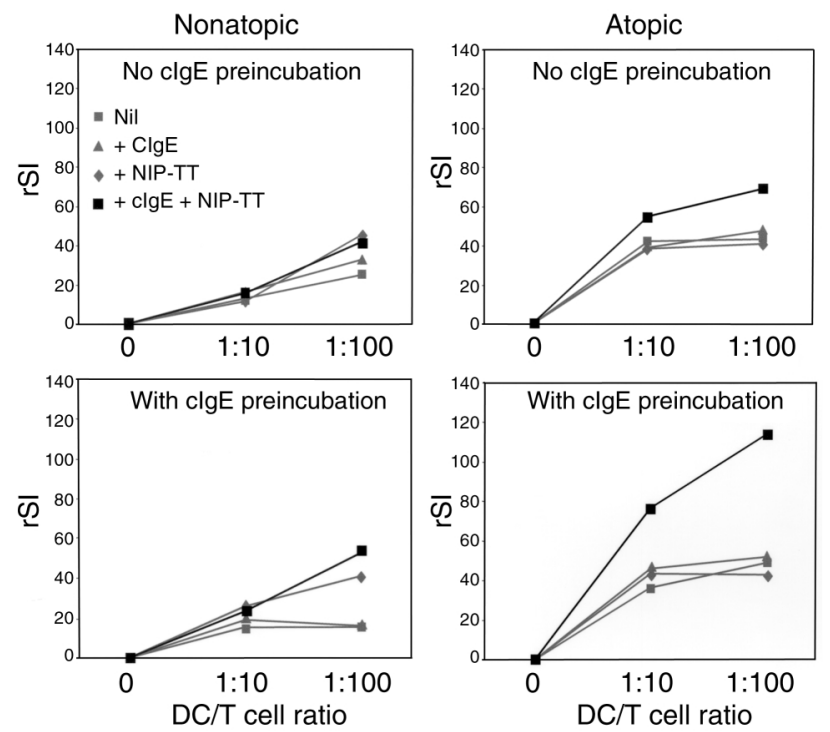

\section{Figure 7}

IgE addition during DC differentiation enhances IgE-dependent stimulatory functions of DCs from atopic donors. MoDCs from nonatopic (left panel) and atopic donors (right panel) were cultured for 6 days with GM-CSF and IL-4 with or without NIP-specific clgE added at days 0,2 , and $4(1 \mu \mathrm{g} / \mathrm{ml})$. IgE-mediated surface FcERI upregulation in atopic donors was controlled by flow cytometry. Then, cells were loaded with $1 \mu \mathrm{g} / \mathrm{ml}$ NIP-specific clgE. After washing and $96 \mathrm{~h}$ of coculture with autologous T cells in a 1:10 or 1:100 ratio of DCs/T cells plus the addition of NIP-TT, T cell proliferation was assessed by ${ }^{3} \mathrm{H}$-thymidine incorporation and $\mathrm{rSI}$ values were calculated from triplicate samples. Negative controls were either IgE or NIP-TT alone or neither, as well as T-cell culture without DCs. Shown are representative data of three experiments for each donor group.

affect FcERI expression and serum-IgE levels by other mechanisms. They detected, however, significant FceRI levels on monocytes from some allergic donors, but not from healthy subjects.

The impressive formation of an intracellular FcERI $\alpha$ pool in immature DCs supports our previous observations, showing constitutive intracellular FcERI $\alpha$ expression in freshly isolated LCs and a modest induction in DCs generated from $\mathrm{CD} 34^{+}$progenitors, but no surface expression $(23,36)$. Thus, we propose that preformed intracellular FceRI $\alpha$, in contrast to monocytes, is characteristic for immature DCs. However, in the previous studies a detailed analysis of FcERI subunit regulation, maturity state, and localization was precluded by the limited availability and purity of cells, making it impossible to purify FceRI $\alpha$ and analyze it by Endo $H$ treatment (23). Intracellular FceRI $\alpha$ in LC-bound IgE, so we concluded that it may represent mature FceRI $\alpha$. While we cannot exclude that LCs may be different from MoDCs at that point, this conclusion may be contrary to the detailed biochemical analyses performed in the present study. However, using an in vitro reconstitution system, immature FceRI $\alpha$ meanwhile has been shown to bind IgE as well (18).

In FceRI assembly and maturation (18-21), it is believed that in the ER folding and N-linked core glycosylation, producing the $\mathrm{G}_{3}$ form of immature FcERI $\alpha$ that bears three terminal glucose residues on high-mannose chains, are followed by trimming of these residues, resulting in $\mathrm{G}_{0 / 1}$ forms of immature FceRI $\alpha$ that bear one or no glucose residues. The export of immature FceRI $\alpha$ from the ER to the Golgi compartment is dependent on correct glucosidase trimming and association with FceRI $\gamma$ chains. In the Golgi compartment, terminal glycosylation with complex sugars takes part, and mature FceRI can then be transported to the cell surface. We detected no Endo $\mathrm{H}$-resistant band at approximately $64 \mathrm{kDa}$ in DCs (Figure 3), which would represent untrimmed $\mathrm{G}_{3}$ forms of immature FceRI $\alpha$ (18). Thus, we conclude that the 50to $60-\mathrm{kDa}$ band represents the correctly trimmed $\mathrm{G}_{0 / 1}$ form of immature FceRI $\alpha$, and a glucosidase defect is not responsible for the lacking FceRI surface expression in FceRI ${ }^{\text {neg }}$ DCs. The Endo H-resistant 60- to 70$\mathrm{kDa}$ band observed in FceRI ${ }^{\mathrm{pos}}$ DCs was considered as mature FceRI $\alpha$, in accordance with reports observing two separate maturity forms of FceRI $\alpha$ with distinct molecular weight $(18,19,37)$.

While intracellular FceRI $\alpha$ protein was present in high amounts, we found a significant correlation of FceRI $\gamma$ expression with FceRI surface levels on DCs. FceRI $\gamma$ is strongly downregulated during DC differentiation and only found to be associated with FceRI $\alpha$ in FceRIpos DCs from atopic donors. These data were confirmed by immunolabeling and laser scan microscopy, which preferentially showed FcERI $\gamma / \mathrm{Fc \varepsilon RI} \alpha$ colocalization in the Golgi compartment in FcERIpos DCs. Thus, we conclude that during DC differentiation, FceRI $\gamma$ becomes the limiting factor for surface expression of the whole complex. This limitation may lead to the accumulation of immature, correctly folded, FceRI $\alpha$ in the ER. Intracellular FcERI $\alpha$ only in the presence of FcERI $\gamma$ is able to leave the ER and acquire full maturity upon terminal glycosylation in the Golgi compartment, thus leading to surface expression of the complex.

Using an in vitro reconstitution system, Albrecht et al. (18) detected immature FcERI $\alpha$ in the ER in the absence of Fc\&RI $\gamma$, a distribution more similar than that we observed in FceRIneg DCs. In contrast, monocytes showed very low levels of intracellular FceRI $\alpha$ but high levels of FceRI $\gamma$, which we think may prevent FceRI $\alpha$ accumulation while leading to surface expression of the FceRI complex. However, these cells also express FcyRI/CD64 and FcyRIII/CD16, both known to associate with FcERI $\gamma$. Due to these additional factors, investigations designed to establish a role of FcERI $\gamma$ in the regulation of FcERI surface expression may not be feasible in this system. As shown in Figure 2c, MoDCs lack these molecules, therefore a possible competition between Fc $\gamma R$ and FceRI $\alpha$ for binding to FceRI $\gamma$ is unlikely in MoDCs. The mechanisms driving association of FceRI $\gamma$ with selected antigen receptors are unclear, however.

To mechanically prove a role of FceRI $\gamma$ in the regulation of FceRI surface levels, it would be desirable to transfect FceRI $\gamma$ into FceRI ${ }^{\text {neg }}$ DCs lacking FceRI $\gamma$ to 
reconstitute FceRI surface expression. The only efficient transfection methods for DCs so far, however, involve adenoviral vectors, which have been reported to induce DC maturation (38). Since maturation leads to downregulation of antigen receptors and to rapid loss of FceRI $\alpha$ transcripts and protein $(2,23)$, this approach is not desirable.

Surface-expressed FceRI has also been reported on eosinophils from hypereosinophilic patients, where it mediates defense against parasites such as Schistosoma mansoni larvae (39). Interestingly, normal human eosinophils contain intracellular FceRI $\alpha$ with low or negative surface levels $(40,41)$. Seminario et al. (40) found FcERI $\gamma$ protein expression in these cells, so they concluded that deficient FceRI $\gamma$ expression was not responsible for that observation. Since eosinophils express all FceRI subunits, at least at the transcriptional level, regulatory mechanisms different from that in APCs bearing trimeric FceRI may be in place $(40,41)$. FceRI $\gamma$ detected in eosinophils, however, has not been shown to be associated with FceRI $\alpha$. It may also be associated with other structures such as Ig $\alpha \mathrm{R} / \mathrm{CD} 89$ expressed on eosinophils $(42,43)$. FcERI $\alpha$ on eosinophils has also been proposed to be secreted, so an association with FceRI $\gamma$ would not be required (40). For DCs, FceRI $\alpha$ secretion is unlikely, since there are no splice variants lacking transmembrane domains both in LCs (23) and MoDCs (S. Kraft, unpublished observation).

In our experiments, IgE sustained FceRI surface levels during DC differentiation. This effect is known from mast cells and basophils (33-35). To our knowledge, the only study documenting an enhancing effect of IgE on FceRI surface expression on primary APCs used monocytes (7). In these experiments, $\mathrm{CHX}$ and $\mathrm{BFA}$ were unable to inhibit the $\mathrm{IgE}$ effect, whereas in our experiments inhibition by both of them was observed, suggesting a rapid turnover of FceRI molecules present at the cell surface. This discrepancy may be due to the different cell systems used. Monocytes quickly undergo apoptosis in the absence of stimuli, so concomitantly de novo synthesis and transport of FceRI chains may be shut down early. In addition, in our experiments IgE incubation did not change the immunophenotype of DCs, so generation of DCs under an "atopic environment" showing high IgE levels may provide a valuable tool for the analysis of FceRI function and signaling in DCs. In our experiments, we could not detect increased synthesis of FceRI $\alpha$ or FceRI $\gamma$ upon IgE addition. The IgE effect, however, was observed only in FceRIpos DCs, suggesting that preexisting surface FceRI and baseline synthesis of both FceRI $\alpha$ and FceRI $\gamma$ are necessary for that effect. So in our view, increased FceRI $\gamma$-mediated surface expression in DCs from atopic donors needs to be a prerequisite for IgE in order to have an effect. Recently, supporting our data on DCs, Borkowski et al. (44) used FcERI-transfected U937 cells to show that the IgE-mediated effect does not depend on the presence of FcERI $\beta$ or increased protein synthesis. They demonstrated that IgE exerts its action by stabilizing surface FceRI, using a preformed FceRI pool as well as baseline FceRI protein synthesis.

The FcERI downregulation observed after terminal maturation of DCs under TNF- $\alpha$ fits to the different functions of immature and mature DCs (2). Immature DCs reside as outposts of the immune system in peripheral tissues and are equipped with receptors facilitating antigen uptake. Upon antigen uptake and additional signals, they migrate to peripheral lymphoid organs, where they present antigens to $T$ cells. This migration is accompanied by a maturation process: it is reflected in a changing immunophenotype with downregulation of antigen receptors and upregulation of surface molecules involved in antigen presentation, such as costimulatory and adhesion molecules.

Atopic diseases such as $\mathrm{AD}$ are characterized by strong upregulation of surface FcERI on DCs, such as epidermal LCs (12). In addition, IDECs are present in inflammatory skin diseases and, in $\mathrm{AD}$, are characterized by very high FceRI surface expression (14). While it is not clear whether these cells primarily express high FceRI levels and then migrate into inflamed skin, or whether they acquire it due to signals they receive during or after migration, the question remains, what enables these cells to upregulate surface FceRI? Upregulation of FceRI $\gamma$ synthesis and high IgE levels during AD may be candidate mechanisms. In contrast to FceRI $\alpha$, the small $\gamma$ chain (7-9 $\mathrm{kDa}$ ) is not subject to extensive posttranslational modification, and so its synthesis presumably is a shorter procedure. The expression of preexisting surface-localized FceRI could then be further enhanced by $\operatorname{IgE}$ binding. The presence of both factors together might lead to enhanced IgE-mediated DC functions further supporting the development of atopic inflammatory reactions, as suggested by our in vitro studies showing enhanced $\mathrm{T}$ cell stimulatory capacity of IgEincubated DCs from atopics (Figure 7).

More information about regulatory factors, however, such as transcription factors determining FceRI $\gamma$ expression in APCs, is needed. In addition to established anti-IgE strategies (45), modulation of FceRI $\gamma$ expression in DCs may represent a potential target for the management of atopic diseases.

\section{Acknowledgments}

We thank J.-P. Kinet (Department of Pathology, Beth Israel Deaconess Medical Center) for critical review of this manuscript. We are grateful to the following persons for gifts of reagents: T. Bjerke, J. Kochan, Y. Misu$\mathrm{mi}$, and Y. Ikehara. The authors thank Mariela Becker from our laboratory for excellent experimental support in investigating IgE-mediated regulation of FceRI. This work was supported by the Deutsche Forschungsgemeinschaft (SFB 284/C8), BONFOR, and Bonner Forum Biomedizin. 
1. Kinet, J.P. 1999. The high-affinity IgE receptor (FcERI): from physiology to pathology. Annu. Rev. Immunol. 17:931-972.

2. Banchereau, J., and Steinman, R.M. 1998. Dendritic cells and the control of immunity. Nature. 392:245-252.

3. Bieber, T., et al. 1992. Human epidermal Langerhans cells express the high affinity receptor for immunoglobulin E (FcERI). J. Exp. Med. 175:1285-1290.

4. Wang, B., et al. 1992. Epidermal Langerhans cells from normal human skin bind monomeric IgE via FcERI. J. Exp. Med. 175:1353-1365.

5. Maurer, D., et al. 1994. Expression of functional high affinity immunoglobulin $\mathrm{E}$ receptors (FcERI) on monocytes of atopic individuals. J. Exp. Med. 179:745-750.

6. Maurer, D., et al. 1996. Peripheral blood dendritic cells express FceRI as a complex composed of FceRI $\alpha$ - and FceRI $\gamma$-chains and can use this receptor for IgE-mediated allergen presentation. J. Immunol. 157:607-616.

7. Reischl, I.G., et al. 1996. Function and regulation of FceRI expression on monocytes from non-atopic donors. Clin. Exp. Allergy. 26:630-641.

8. Mudde, G.C., et al. 1990. Allergen presentation by epidermal Langerhans' cells from patients with atopic dermatitis is mediated by IgE. Immunology. 69:335-341.

9. Maurer, D., et al. 1995. The high affinity IgE receptor (FcERI) mediates IgE-dependent allergen presentation. J. Immunol. 154:6285-6290.

10. Bieber, T. 1996. FceRI on antigen-presenting cells. Curr. Opin. Immunol. 8:773-777.

11. Bieber, T. 1997. FceRI-expressing antigen-presenting cells: new players in the atopic game. Immunol. Today. 18:311-313.

12. Jürgens, M., Wollenberg, A., Hanau, D., de la Salle, H., and Bieber, T. 1995. Activation of human epidermal Langerhans cells by engagement of the high affinity receptor for IgE, FceRI. J. Immunol. 155:5184-5189.

13. Gosset, P., et al. 2001. Modulation of high-affinity IgE receptor expression in blood monocytes: opposite effect of IL-4 and glucocorticoids. J. Allergy Clin. Immunol. 107:114-122.

14. Wollenberg, A., Kraft, S., Hanau, D., and Bieber, T. 1996. Immunomorphological and ultrastructural characterization of Langerhans cells and a novel, inflammatory dendritic epidermal cell (IDEC) population in lesional skin of atopic eczema. J. Invest. Dermatol. 106:446-453.

15. Miller, L., Blank, U., Metzger, H., and Kinet, J.P. 1989. Expression of highaffinity binding of human immunoglobulin $\mathrm{E}$ by transfected cells. Science. 244:334-337.

16. Küster, H., Thompson, H., and Kinet, J.P. 1990. Characterization and expression of the gene for the human Fc receptor $\gamma$ subunit. Definition of a new gene family. J. Biol. Chem. 265:6448-6452.

17. Ryan, J.J., Kinzer, C.A., and Paul, W.E. 1995. Mast cells lacking the high affinity immunoglobulin E receptor are deficient in FcERI $\gamma$ messenger RNA. J. Exp. Med. 182:567-574.

18. Albrecht, B., Woisetschlager, M., and Robertson, M.W. 2000. Export of the high affinity IgE receptor from the endoplasmic reticulum depends on a glycosylation-mediated quality control mechanism. J. Immunol. 165:5686-5694.

19. Donnadieu, E., Jouvin, M.H., and Kinet, J.P. 2000. A second amplifier function for the allergy-associated FcERI- $\beta$ subunit. Immunity. 12:515-523.

20. Letourneur, O., Sechi, S., Willettebrown, J., Robertson, M.W., and Kinet, J.P. 1995. Glycosylation of human truncated FcERI $\alpha$ chain is necessary for efficient folding in the endoplasmic reticulum. J. Biol. Chem. 270:8249-8256.

21. Letourneur, F., Hennecke, S., Demolliere, C., and Cosson, P. 1995. Steric masking of a dilysine endoplasmic reticulum retention motif during assembly of the human high affinity receptor for immunoglobulin E. J. Cell Biol. 129:971-978.

22. Reischl, I.G., et al. 2000. Regulation of FceRI expression on human monocytic cells by ligand and IL-4. Clin. Exp. Allergy. 30:1033-1040.

23. Kraft, S., Wessendorf, J.H., Hanau, D., and Bieber, T. 1998. Regulation of the high affinity receptor for IgE on human epidermal Langerhans cells. J. Immunol. 161:1000-1006.
24. Sallusto, F., and Lanzavecchia, A. 1994. Efficient presentation of soluble antigen by cultured human dendritic cells is maintained by granulocyte/macrophage colony-stimulating factor plus interleukin 4 and downregulated by tumor necrosis factor alpha. J. Exp. Med. 179:1109-1118.

25. Riske, F., et al. 1991. High affinity human IgE receptor (FcERI). Analysis of functional domains of the $\alpha$-subunit with monoclonal antibodies. J. Biol. Chem. 266:11245-11251.

26. Schöneich, J.T., Wilkinson, V.L., Kado-Fong, H., Presky, D.H., and Kochan, J.P. 1992. Association of the human FcERI $\gamma$ subunit with novel cell surface polypeptides. J. Immunol. 148:2181-2185.

27. Vivier, E., et al. 1991. Expression and tyrosine phosphorylation of the T cell receptor $\zeta$-subunit in human thymocytes. J. Immunol. 146:1142-1148

28. Pirron, U., Schlunck, T., Prinz, J.C., and Rieber, E.P. 1990. IgE-dependent antigen-focusing by human B lymphocytes is mediated by the low-affinitiy receptor for IgE. Eur. J. Immunol. 20:1547-1551.

29. Saini, S.S., et al. 2000. The relationship between serum IgE and surface levels of FcER on human leukocytes in various diseases: correlation of expression with FceRI on basophils but not on monocytes or eosinophils. J. Allergy Clin. Immunol. 106:514-520.

30. Ra, C., Jouvin, M.H., Blank, U., and Kinet, J.P. 1989. A macrophage Fc $\gamma$ receptor and the mast cell receptor for IgE share an identical subunit. Nature. 341:752-754.

31. Ernst, L.K., Duchemin, A.M., and Anderson, C.L. 1993. Association of the high-affinity receptor for $\operatorname{IgG}(\mathrm{Fc} \gamma \mathrm{RI})$ with the $\gamma$-subunit of the IgE receptor. Proc. Natl. Acad. Sci. U. S. A. 90:6023-6027.

32. Ra, C., Jouvin, M.H., and Kinet, J.P. 1989. Complete structure of the mouse mast cell receptor for IgE (FcERI) and surface expression of chimeric receptors (rat-mouse-human) on transfected cells. J. Biol. Chem. 264:15323-15327.

33. MacGlashan, D., et al. 1998. In vitro regulation of FcERI $\alpha$ expression on human basophils by IgE antibody. Blood. 91:1633-1643.

34. Lantz, C.S., et al. 1997. IgE regulates mouse basophil FceRI expression in vivo. J. Immunol. 158:2517-2521.

35. Yamaguchi, M., et al. 1997. IgE enhances mouse mast cell FcERI expression in vitro and in vivo: evidence for a novel amplification mechanism in IgE-dependent reactions. J. Exp. Med. 185:663-672.

36. Geiger, E., et al. 2000. IL-4 induces the intracellular expression of the $\alpha$-chain of the high-affinity receptor for $\operatorname{IgE}$ in in vitro-generated dendritic cells. J. Allergy Clin. Immunol. 105:150-156.

37. Saini, S.S., et al. 2001. Expression and modulation of FcERI $\alpha$ and FceRI $\beta$ in human blood basophils. J. Allergy Clin. Immunol. 107:832-841.

38. Morelli, A.E., et al. 2000. Recombinant adenovirus induces maturation of dendritic cells via an NF-KB-dependent pathway. J. Virol. 74:9617-9628.

39. Gounni, A.S., et al. 1994. High-affinity $\operatorname{IgE}$ receptor on eosinophils is involved in defence against parasites. Nature. 367:183-186.

40. Seminario, M.C., Saini, S.S., MacGlashan, D.W., and Bochner, B.S. 1999. Intracellular expression and release of FcERI $\alpha$ by human eosinophils. J. Immunol. 162:6893-6900.

41. Smith, S.J., et al. 2000. Blood eosinophils from atopic donors express messenger RNA for the $\alpha$-, $\beta$-, and $\gamma$-subunits of the high-affinity IgE receptor (FcERI) and intracellular, but not cell surface, $\alpha$-subunit protein. J. Allergy Clin. Immunol. 105:309-317.

42. Morton, H.C., van Egmond, M., and van de Winkel, J.G. 1996. Structure and function of human IgA Fc receptors (FcoR). Crit. Rev. Immunol. 16:423-440.

43. Pfefferkorn, L.C., and Yeaman, G.R. 1994. Association of IgA-Fc receptors $(\mathrm{Fc} \alpha \mathrm{R})$ with $\mathrm{Fc \varepsilon R} \gamma 2$ subunits in U937 cells. Aggregation induces the tyrosine phosphorylation of $\gamma 2$. J. Immunol. 153:3228-3236.

44. Borkowski, T.A., Jouvin, M.H., Lin, S.Y., and Kinet, J.P. 2001. Minimal requirements for IgE-mediated regulation of surface FcERI. J. Immunol. 167:1290-1296

45. Milgrom, H., et al. 1999. Treatment of allergic asthma with monoclonal anti-IgE antibody. rhuMAb-E25 Study Group. N. Engl. J. Med. 341:1966-1973. 